\title{
EFFECTS OF TILLAGE SYSTEM - CORN VARIETY COMBINATIONS ON AIRBORNE DISEASES
}

\author{
Joko Prasetyo ${ }^{1}$
}

ABSTRAK

\begin{abstract}
Pengaruh Kombinasi Sistem Olah Tanah dan Varietas Jagung terhadap Penyakit-penyakit Terbawa Udara. Suatu percobaan telah dilakukan untuk mengetahui pengaruh kombinasi sistem olah tanah dan varietas jagung terhadap beberapa penyakit atau patogen terbawa udara, yaitu patogen bulai, karat, dan hawar daun. Percobaan ini disusun secara faktorial (2 x 3) dalam rancangan acak kelompok lengkap dengan enam ulangan. Percobaan terdiri dari enam kombinasi perlakuan, yaitu varietas RR-corn ditanam pada sistem olah tanah konservasi (RRCT), C7 ditanam pada sistem olah tanah konservasi (C7CT), Bisma ditanam pada sistem olah tanah konservasi (BCT), RR-corn ditanam pada sistem olah tanah sempurna (RRFT), C7 ditanam pada sistem olah tanah sempurna (C7FT), dan Bisma ditanam pada sistem olah tanah sempurna BFT). Hasil percobaan menunjukkan bahwa secara nyata kombinasi sistem olah tanah dan varietas jagung mempengaruhi intensitas penyakit. Kombinasi sistem olah tanah dan varietas jagung berpengaruh terhadap penyakit bulai. Varietas jagung yang ditanam pada sistem olah tanah konservasi secara nyata menurunkan intensitas penyakit bulai dibandingkan dengan varietas jagung yang ditanam pada sistem olah tanah sempurna, kecuali varietas Bisma. Hasil penelitian juga menunjukkan bahwa varietas Bisma dapat menurunkan intensitas penyakit bulai dibandingkan dengan varietas RR-corn dan C7 pada sistem olah tanah sempurna. Kombinasi sistem olah tanah dan varietas jagung berpengaruh terhadap intensitas penyakit karat. Pada sistem olah tanah konservasi, secara nyata varietas C7 menurunkan intensitas penyakit karat dibandingkan dengan RR-corn dan Bisma. Varietas RR-corn dan Bisma menurunkan intensitas penyakit karat bila ditanam pada sistem olah tanah sempurna bila dibandingkan dengan yang ditanam pada sistem olah tanah konservasi. Kombinasi sistem olah tanah dan varietas jagung juga secara nyata berpengaruh terhadap intensitas penyakit hawar daun. Varietas RR-corn dan Bisma yang ditanam pada sistem olah tanah sempurna menurunkan intensitas penyakit hawar daun bila dibandingkan dengan yang ditanam pada sistem olah tanah konservasi.
\end{abstract}

Key words: tillage, corn, airborne diseases

\section{INTRODUCTION}

Corn is frequently grown in monocrop system in Indonesia. Several diseases are known to attack corn. These diseases include leaf blight (Helminthosporium spp.), rust (Puccinia spp.), downy mildew (Peronosclerospora maidis), yellow corn leaf blight (Phylosticta maidis), brown spot (Physoderma maidis), and anthracnose (Colletotrichum graminicola). The first three diseases are common and important diseases in Indonesia.

The other main problem of corn production is how to manage weeds. So far, the management of weeds still needs high cost, particularly for full tillage system. Other than the problem, the implementation of full tillage in the long time results severe soil erosions. Soil erosions degrade soil structure, decrease soil fertility, and reduce the number of soil microorganism, including vesicular-arbuscular mycorrhizae. Allen and Boosalis (1983) cit. Yokom et al. (1985) showed that mycorrhizal fungi population decreased under wheat-fallow rotation compared to grassland. Kruckelmman (1975) showed that tilling by rotary hoe tended to decrease spore number of mycorrhizal fungi. The decrease of mycorrhizal fungi may result in the decrease of plant health. From the study of many experts were revealed that mycorrhizal fungi have significant role in disease resistance.

Reduced tillage system have been established in some areas of Indonesia and will become increasingly important in other areas where soil moisture and erosion impact on crop production. Continuing expansion of conservation tillage throughout Indonesia relates to erosion, energy limitations, and drought. The other side of conservation tillage is that it affects the dynamic of many diseases. Corn is grown in monocrop system in Indonesia, and much of the acreage is now grown under various types of minimum tillage and conservation tillage systems. Most of the diseases, like leaf blight, brown spot, anthracnose, and gray leaf spot, are predicted more severe in minimal tillage than when corn debris is buried by plowing (Sumner et al.,

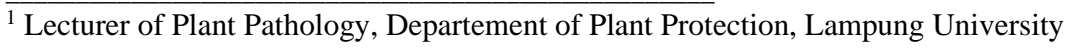


1981). Beside that, the negative side of reduced tillage is the dependency of this practice on herbicide.

The herbicide application could decrease the management cost, but there could be negative side effects. Usually, the herbicide applications cause phytotoxic to plant. Phytotoxicity retards plant growth and development. Thus, the herbicide must be applied very carefully.

Application of conservation tillage by using herbicide is a rational way of weed management. As mention above, the problem is phytotoxic effect of the herbicide to the plants. Cultivar RR-corn promises to solve this problem. Cultivar RR-corn has tolerant character to glyphosate spraying (Kishore et al., 1992). However, many reports showed that the use of chemical materials to the soil caused negative side effects to vesicular-arbuscular mycorrhizae. The decrease of vesicular-arbuscular mycorrhizae may result in the decrease of plant resistance against some diseases. The present study was intended to reveal the effects of tillage system-corn variety combination on downy mildew, rust, and leaf blight.

\section{METHODS}

The field experiment was conducted in Natar, South Lampung, from July to September 2001. The experiment was done in the agricultural experimental station, Balai Pengkajian Teknologi Pertanian, Lampung.

The experiment consisted of two factors (2x3). The first factor was tillage systems (CT and FT) and the second factor was corn cultivars (RR, C7, and Bisma). The treatments were cultivar RR-corn grown under conservation tillage system (RRCT), C7 grown under conservation tillage system (C7CT), Bisma grown under conservation tillage system (BCT), RR-corn grown under full tillage system, C7 grown under full tillage system (C7FT), and Bisma grown under full tillage system (BCT). The treatment were arranged in completely randomized block design with six replicates. In the full tillage system, the land was plowed completely, while in the conservation tillage system, herbicide (glyphosate) was sprayed over the plots. The glyphosate was sprayed blanketly over the plots before the seeds sowed, and sprayed between row after the plants emerged from the soil.

Measured variables were disease intensities of downy mildew, leaf blight, and rust. The downy mildew intensity was calculated by dividing the number of plants showing downy mildew symptom with all sample plants and expressed in percent, while rust and leaf blight was calculated by this formula:

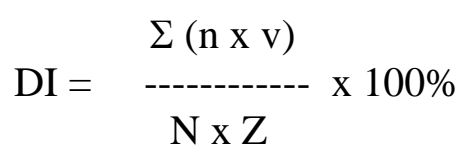

where DI = disease intensity

$\mathrm{N}$ = number of leaf samples

$\mathrm{Z}=$ the highest score

$\mathrm{v}=$ disease score: $0=$ no symptom; $1=1-<25 \% ; 2=25-<50 \%$; $3=50-<75 \%$; and $4=75-100 \%$.

$\mathrm{N}=$ leaves number of each score.

F test and LSD test at 0,05 level were used to analysed to the variable.

\section{RESULTS AND DISCUSSION}

The results of the experiment showed that RRCT and C7CT significantly decreased downy mildew intensity compared to RRFT and C7FT respectively (Table 1). BFT significantly decreased downy mildew intensity compared to RRFT and C7FT. There was no difference between BFT and BCT, and there was also no difference between all cultivars tested in the conservation tillage system.

The decrease of RRCT and C7CT compared to RRFT and C7FT respectively may due to the indirect effect of mycorrhizal infection. In the low soil $\mathrm{P}$ content, mycorrhizal fungi increase the availability of soil P, and then increase the plant health. In this experiment, the availability of soil $\mathrm{P}$ was enough, so the plants did not need the presence of mycorrhizal fungi. In this experiment the decrease of mycorrhizal infection increased plant health, and then decreased downy mildew intensity.

The decrease of BFT compared to RRFT and C7FT may due to the difference in plant resistance. It indicates that cultivar Bisma is better than RR and C7 in plant resistance against downy mildew.

The results of the experiment showed that C7CT significantly decreased rust intensity compared to BCT and RRCT (Table 1). There was no difference on rust intensity in all cultivar tested in the full tillage system. Cultivar RR and Bisma grown in the full tillage system significantly decreased rust intensity compared to the both cultivar grown in conservation tillage system.

The decrease of rust intensity in C7CT compared to RRCT and BCT may due to cultivar C7 
Table 1 . The effects of tillage system - corn variety combinations on downy mildew, rust, and leaf blight intensity (\%)

\begin{tabular}{cccc}
\hline \multirow{2}{*}{$\begin{array}{c}\text { Tillage Systems and } \\
\text { Corn Varieties }\end{array}$} & Downy Mildew & Rust & Leaf Bligt \\
\cline { 2 - 4 } Conservation Tillage & & \\
\hline RR & $12.0 \mathrm{~b}$ & $41.7 \mathrm{a}$ & $9.6 \mathrm{ab}$ \\
C7 & $15.9 \mathrm{~b}$ & $29.9 \mathrm{c}$ & $7.8 \mathrm{~b}$ \\
Bisma & $6.8 \mathrm{~b}$ & $37.8 \mathrm{ab}$ & $11.1 \mathrm{a}$ \\
Full Tillage & & & \\
RR & $31.5 \mathrm{a}$ & $33.6 \mathrm{bc}$ & $5.6 \mathrm{c}$ \\
C7 & $30.3 \mathrm{a}$ & $31.8 \mathrm{c}$ & $7.9 \mathrm{~b}$ \\
Bisma & $4.4 \mathrm{~b}$ & $30.3 \mathrm{c}$ & $8.0 \mathrm{~b}$
\end{tabular}

Notes: Average number in the same column followed by different letters are significantly different, while those followed by the same letters are not significantly different after LSD test ( $\alpha=0.05$ ).

is more resistant than RR and Bisma. Possibly, rust resistant character in cultivar RR have lost for the insertion of glyphosate resistant character. Genetically, cultivar RR and C7 is the same, but glyphosate resistant character.

The decrease of rust intensity of cultivar RR and Bisma grown in the full tillage compared to grown in conservation tillage system may due to low humidity in the both plots of full tillage system. The canopy of RR and Bisma plants in conservation tillage system were better than in full tillage system, the humidity higher and the disease more intense.

The result of the experiment showed that C7CT decreased leaf blight intensity compared to BCT (Table 1). Cultivar RR-corn and Bisma grown in the full tillage system significantly decreased leaf blight intensity compared to the both cultivars grown in the conservation tillage system. There was no differences in leaf blight intensity between C7 in both tillage system.
The decrease of C7CT compared to RRCT and BCT may due to the difference in plant resistance. It indicates that cultivar C7 is better RR and Bisma in plant resistance against leaf blight.

The decrease of RRFT and BFT compared to RRCT and BCT respectively may due to the better survival of Helminthosporium spp. or lower humidity in plots RRFT and BFT. This result was supported by Boosalis et al. (1981 cit. Sumner, 1981). The canopies of RR and Bisma in the conservation tillage system were better than in the full tillage system.

\section{CONCLUSION}

RRCT and C7CT significantly decreased downy mildew intensity compared to RRFT and C7FT respectively. In the full tillage system, Bisma was more resistant against downy mildew compared to cultivar RR and C7. 
C7CT was more resistant against rust compared to RRCT and BCT. RRFT and BFT decreased rust intensity compared to RRCT and BCT respectively.

C7 was more resistant compared to Bisma, both grown in the conservation tillage system. RRFT and BFT significantly decreased leaf blight intensity compared to RRCT and BCT respectively.

\section{ACKNOWLEDGMENT}

I thank to M. Utomo, F.X. Susilo, and G. Swibawa for their assistance. This research was funded by Monsanto Corporation.

\section{REFERENCES}

Kishore, G.M., S.R. Padgette, \& R.T. Freley. 1992. History of herbicide tolerant crops, methods of developtment, and current state of the art emphasis on glyphosate tolerance. Weed Tech. 6: 626-634.

Kruckelmman, H.W. 1975. Effect of fertilzer, soil, soil tillage, and plant species on the frequency of endogone chlamidospores and mycorrhizal infection in arable soil. Pages: 512-525, in Endomycorrhizas. F.E. Sanders, B. Mosse, and P.B. Tinkers (eds.) Academic Press, London.

Sumner, D.R., B. Doupnik, \& M.G. Boosalis. 1981. Effects of reduced tillage and multiple cropping on plant diseases. Ann. Rev. Phytopathol. 19: 167-187.

Yokom, D.H., H.J. Larsen, \& M.G. Boosalis. 1985. The effect of tillage treatments and fallow seasons on V.A Mycorrhizae of winter wheat. Page: 297, in Proceeding of the $6^{\text {th }}$ North American Confference on Mycorrhizae. R. Molina (ed.) Forest Research Laboratory, Bend, Oregon. 
Table 1. The effects of tillage system - corn variety combinations on downy mildew, rust, and leaf blight intensity (\%)

\begin{tabular}{cccc}
\hline \multirow{2}{*}{$\begin{array}{c}\text { Tillage Systems and } \\
\text { Corn Varieties }\end{array}$} & \multicolumn{3}{c}{ Diseases Intensity (\%) } \\
\cline { 2 - 4 } Conservation Tillage & Rowny Mildew & Leaf Bligt \\
\hline RR & $12.0 \mathrm{~b}$ & $29.9 \mathrm{c}$ & $9.6 \mathrm{ab}$ \\
C7 & $15.9 \mathrm{~b}$ & $37.8 \mathrm{ab}$ & $7.8 \mathrm{~b}$ \\
Bisma & $6.8 \mathrm{~b}$ & & $11.1 \mathrm{a}$ \\
Full Tillage & & $33.6 \mathrm{bc}$ & $5.6 \mathrm{c}$ \\
RR & $31.5 \mathrm{a}$ & $31.8 \mathrm{c}$ & $7.9 \mathrm{~b}$ \\
C7 & $30.3 \mathrm{a}$ & $30.3 \mathrm{c}$ & $8.0 \mathrm{~b}$ \\
Bisma & $4.4 \mathrm{~b}$ & \multicolumn{3}{c}{$\mathrm{c}$} \\
\hline
\end{tabular}

Notes: Average number in the same column followed by different letters are significantly different, while those followed by the same letters are not significantly different after LSD test ( $\alpha=0.05$ ). 